\title{
STATUS AND ANALYSES OF SOCIAL ECONOMY IN GIMHAE-SI, SOUTH KOREA
}

\author{
MINJI KIM, EUITAY JUNG
}

\begin{abstract}
:
Social economy has received attention as an inclusive growth model which solves various social problems and at the same time, responds to structural low growth. Especially, it has appeared as an alternative to solve social problems including the high rate of unemployment, job insecurity, and the gap between the rich and the poor as it was selected as one of 100 national agendas for state affairs government projects since the inauguration of the new government. In Korea, people are growing more and more interested in social economy as the legal bases related to social economy including 'the Social Enterprise Promotion Act' in 2007 and 'the Framework Act on cooperatives' in 2012 were prepared.

Gimhae first enacted an ordinance for revitalizing social economy in Gyeongsangsnam-do to do community projects by supporting social enterprises' foundation and development and will first establish a 'social economy support center'in September, 2018 in the Yeongnam area.

This study tries to analyze the characteristics and support policies of social economy in Gimhae by doing its theory and the general status of its organizations including social enterprises, cooperatives, community-based enterprises, and self-support companies in it, and by conducting interview style surveys on activists of social economy organizations of Gimhae.

For current social economy of Gimhae, the number of businesses is lower than that of other local governments and there would be companies suffering practical operation. Normalizing operation is needed through implementation of consulting for suspended companies. Gimhae is still at a rudimentary stage despite great efforts to develop it.

Therefore, for facilitation and growth of Gimhae city's social economy, not a policy focusing only on quantitative index growth, but consulting and proactive promotion, finance and education support are needed for improving autonomy of sustainable social economy organizations. Rather than direct support of the government and local autonomous governments, specialized support activities where civilians participate in Gimhae city's social economy support center. The study tries to provide basic materials of social economy in Gimhae and seek for solutions to develop and revitalize it in the future.
\end{abstract}

\section{Keywords:}

Gimhae-si, Social Economy, Policy

\section{Authors:}

MINJI KIM, Inje University, South Korea, Email: kj3100@hanmail.net

EUITAY JUNG, Inje University, South Korea, Email: dejet@inje.ac.kr

\section{Citation:}


MINJI KIM, EUITAY JUNG (2019). Status and Analyses of Social Economy in Gimhae-si, South Korea. International Journal of Social Sciences, Vol. VIII(1), pp. 1-16., 10.20472/SS.2019.8.1.001 


\section{Introduction}

Korea' s social economy achieved rapid economic growth by actively pushing for government-led social economic organization fostering with the start of job creating project in 2003. In December 2006, 「Social Company Fostering Law」 was enacted, there are social companies, cooperative union, and village company ${ }^{1}$.

Operation agents and areas became various, and many social companies which deal with socially weak classes emerged, which is a phenomenon reflecting growing interest in social companies ${ }^{2}$. However, there are insufficient researches on social economy of Gimhae city, and there is a need for more researches and support for systematic social economy development of social companies.

This research examined theories and current situations about social economy, and analyzed characteristics and support policy of Gimhae city by analyzing general situation of social economy organizations such as social company, cooperative union, village company, and self-support company and by conducting interview-type surveys on activists of social economy organizations of Gimhae city.

\section{Social Economy}

Social economy means all of the economic activities seeking common benefits and social value realization through mutual cooperation and solidarity among members ${ }^{3}$. Social Economy is a measure against protection of workers exposed to other social danger different from the past agricultural area, the emergence of industry centered economy, and social danger caused by this economic system, and social economy emerged as a solution to these problems of modern industrialization ${ }^{4}$.

Social economy organizations include (prospective)social company, (social)cooperative union, or (social)cooperative union association, community-based company, selfsupporting company, manufacturing facility of severely disabled people's products, farming and fishing village community company, and companies which conduct economic activities for the purpose of realizing social values according to the standards determined

\footnotetext{
${ }^{1}$ Lee Yu Ri. A Study on the Current Stateand Development Plan of Social Economic Organization -Focusing the Jeollanamdo-. Mokpo university master's thesis. 2015

${ }^{2}$ Kwon Eun Sil, A Study on the Present Situation and development measures of Social Enterprise -With Emphasis on Daegu and North Gyeongsang Province-, Daegu university master's thesis, 2011

${ }^{3}$ Ministry of Strategy and Finance of the Republic of Korea

${ }^{4}$ Kwon Eun Sil, A Study on the Present Situation and development measures of Social Enterprise -With Emphasis on Daegu And North Gyeongsang Province-, Daegu university master's thesis, 2011
} 
by markets such as shared economy and fair trade, and non-profit corporation or nonprofit civil groups ${ }^{1}$.

\subsection{Korea's Social Economy}

Korea' s first social economic organization which emerged after the Japanese colonial rule is 'Seongga credit cooperative union' established in Busan in 1960, and it began to spread in earnest since legislation of credit cooperative union law in 1972. In 1980, consumer cooperative union movement began to be stood out, and in 1988 it began to be developed centering on Hansalim consumer life cooperative union to be the most developed organization in Korea's social economy. The growth of social economy became earnest since 2000, and the implementation of 'social company fostering law' in 2007 was the momentum. Cooperative union basic law implemented since December, 2012 has sparked the establishment of multi-purpose cooperative union. Since the implementation of the institution until the second half of 2014 , more than 5,000 cooperative unions were established throughout the nation².

Korea' s social economy was government-led union type until 1970s, and the social economy movement in the 1990s was included mostly into welfare system, and earnest movement of social economy in Korea did not begin until 21st century after the financial crisis $^{3}$. The current social economy of Korea includes social company, cooperative union, village company, self-governing community, social job project organization, and worker cooperative union, and living cooperative union, medical living cooperative union, and joint child caring cooperative union which conducts economic activities related to consumption ${ }^{4}$. Among them, in terms of policy, social companies, cooperative unions, and community-based companies are usually considered ${ }^{5}$.

Table 1: Institutionalization process of Korea's social economy

\begin{tabular}{|l|l|l|l|}
\hline Period & Law/Institution & Features & $\begin{array}{l}\text { Characteristic } \\
\text { s }\end{array}$ \\
\hline$\sim 1970$ s & Nonghyup law, Credit Union Law & $\begin{array}{l}\text { Compulsory } \\
\text { institutionalization }\end{array}$ & Oppressive \\
\hline 1997 & $\begin{array}{l}\text { Self-supporting project } \\
\text { Delegation project of public work to civil }\end{array}$ & $\begin{array}{l}\text { Institutionalization of } \\
\text { labor integrating type }\end{array}$ & Instrumental \\
\hline
\end{tabular}

\footnotetext{
${ }^{1}$ ModuCoop, Comparative study of social economy-related regulations and policies across the nation's metropolitan cities -Focusing social company, cooperative union-

${ }^{2}$ Kim Seong Gi et al. 4. Public market marketing for social economy companies-for innovative public service-Arche 2015

${ }^{3}$ Social Share Economy Facilitation Strategy of Gimhae City, 2015

${ }^{4}$ Lee Yu Ri. A Study on the Current Stateand Development Plan of Social Economic Organization -Focusing the Jeollanamdo-. Mokpo university master's thesis. 2015

${ }^{5} \mathrm{Kim}$ Seong Gi et al. 4. Public market marketing for social economy companies-for innovative public service-Arche 2015
} 


\begin{tabular}{|c|c|c|c|}
\hline & sectors & \multirow{7}{*}{$\begin{array}{l}\text { social economy } \\
\rightarrow \\
\text { Institutionalization of } \\
\text { social service type } \\
\text { social economy }\end{array}$} & \multirow{6}{*}{$\begin{array}{l}\text { Hegemonic } \\
\text { Mobility }\end{array}$} \\
\hline 2000 & National Basic Livelihood Security Act & & \\
\hline 2003 & Social job project & & \\
\hline 2007 & $\begin{array}{l}\text { Social company fostering law } \\
\text { (Ministry of Labor) }\end{array}$ & & \\
\hline 2010 & $\begin{array}{l}\text { Special law on supporting city } \\
\text { revitalization }\end{array}$ & & \\
\hline 2011 & $\begin{array}{l}\text { Special law on improving the quality of life } \\
\text { of people in agriculture and fishery } \\
\text { (Ministry of Agriculture, Food, and Rural } \\
\text { Areas) }\end{array}$ & & \\
\hline 2012 & $\begin{array}{l}\text { Basic law on cooperative union } \\
\text { (Ministry of Economy and Finance) }\end{array}$ & & \multirow[t]{2}{*}{$\begin{array}{l}\text { Neoliberalism } \\
\text { governance }\end{array}$} \\
\hline 2014 & Motion of basic law on social economy & $\begin{array}{l}\text { Political } \\
\text { institutionalization }\end{array}$ & \\
\hline
\end{tabular}

Source: Lee Hae Jin. 2015. "Korea's social economy-political process of institutionalization and regionalization strategy" "Regional sociology』 Volume 16, Issue 1.

Recently, as a measure to resolve various problems such as unemployment, poverty, and regional development, social economy organization increased rapidly in quantity over the past 10 years through policies of related government organizations such as the Ministry of Employment and Labor, the Ministry of Strategy and Finance, the Ministry of Interior and Safety, the Ministry of Health and Welfare, and the Ministry of Agriculture, Food and Rural Affairs ${ }^{1}$. With the government' attention, institutional environment has been made little by little for vitalizing social economy, as one of 100 national political agenda, in order to implement social economy, central government and local autonomous governments are actively making efforts by making institutional foundation ${ }^{2}$ and local autonomous government social economy support center conducts projects to secure finance resources needed for local autonomous government social economy support for selfsupporting ability and sustainable growth of social economy organizations such as social company, cooperative union, and village company ${ }^{3}$.

\footnotetext{
${ }^{1}$ Five researchers including Lim Sang Yeon and et al. Measures to utilize social economy organization for increasing ciy vitality. KRIHS POLICY BRIEF. no. 556. 2016

2 Lee Yu Ri. A Study on the Current Stateand Development Plan of Social Economic Organization -Focusing the Jeollanamdo-. Mokpo university master's thesis. 2015

${ }^{3}$ Korea Basic Law on Social Economy
} 
Social economy support center aims at facilitating social economy and building sustainable social economy ecosystem in a city and province, and implements-manages facility expense, education training, promotion, financial support and social economy development fund raising, and special guarantee ${ }^{1}$. As for representative policies, there are citizen-society related educational project, governance building project, policy development project, management support industry, Pro Bono, advice-consulting project, personnel expense support project, project development support project, market building and on-offline joint store, and promotion and citizen proliferation project.

The number of social company certified in Korea is 1,877 as of January, 2018, suggesting rapid growth from 446 in 2007 . The number of cooperative union is 12,556 in total, and there are general cooperative union, social cooperative union, general cooperative union association, and social cooperative union association.

\subsection{Social Economy in Foreign Countries}

Historically, social economy movement developed in Europe centering on the U.K. and France. The early stage of social economy originated from utopian community movement replacing capitalism and started from the late 18th century. The pioneer of this movement is Robert Owen who experimented labor community called New Harmony. His ideology affected the birth of consumers' cooperative union in the U.K. and spread to European continent $^{2}$. The term of social economy was first used by Charles Dunoyer, a French economist in 1830, but it began to be used in earnest by Charles Gide, a French economic ideologist around 1900s in the more modern meaning. From the late 1980s, the concept of France's 'social economy' began to spread to neighboring countries in Europe. As jobless growth persisted since the mid 1990, and the demand for social service because of population aging and changes in family structure increased, social economy organizations received attention as alternative actors for creating jobs and supplying social services, and social economy began to boom again ${ }^{3}$. Social economy took center stage again as a social solution to respond to failure of capitalistic market and failure of welfare country which cause inequality, poverty, and market monopoly ${ }^{4}$. Current social economy of Europe accounts for $10 \%$ of the entire European businesses, and more than 20 million are employed by 2 million businesses ${ }^{5}$. In Europe, social economy sectors include social company, cooperative union, mutual benefit association, private

\footnotetext{
${ }^{1}$ ModuCoop. Comparative study of social economy-related regulations and policies across the nation's metropolitan cities -Focusing social company, cooperative union-

${ }^{2}$ Kim Seong Gi et al. 4. Public market marketing for social economic companies-for innovative public service-Arche. 2015

${ }^{3}$ Lee Yu Ri. A Study on the Current Stateand Development Plan of Social Economic Organization -Focusing the Jeollanamdo-. Mokpo university master's thesis. 2015

4 Social Share Economy Facilitation Strategy of Gimhae City. 2015

${ }^{5}$ Social Economy Europe. www.socialeconomy.eu.org.
} 
organization, and foundation ${ }^{1}$. As for Europe's social economy ratio, according to comparison between the European Union's entire paid workers and social solidarity economy paid workers between 2009 2010 of the social economy in the European Union (2014), CIRIEC, social economy jobs in 15 European countries account for $7.41 \%$ in the entire wage sector. In the meantime social economy actors of 27 European countries including new member nations gainfully employ 14.5 million people, about $6.5 \%$ of the entire labor population ${ }^{2}$. According to France' s social solidarity economy, currently $2,370,310$ employees are employed in 221,325 social economy organizations. Total production of social solidarity economy accounts 10 11\% of GDP. For the first time in 10 years, the number of regular workers surpassed 2 million, and the ratio of the employment by social solidarity economy increased from $10.3 \%$ to $10.5 \%$ in the entire economy. Private organization(Association) create the most employment at $78 \%$ followed by $13 \%$, and cooperative association and foundation are small in number and the employment ratio continues to increase since $2010^{3}$.

With the support system of successful social company in Europe, France has very developed independent self-employed businesses and small companies' cooperative unions. As social company support system, there are labor cooperative union association(CGSCOP), commercial cooperative union groups, and as interest groups there are lobby, legislature, advisory, and promotion activities. The U.K. conduct vibrant consulting and consignment business with expertise in fund operation. In Sweden, coompanion is at the center with the focus on cooperative union development, consulting, and regional development project ${ }^{4}$.

\section{Table 2: Europe's social company support system}

\begin{tabular}{|c|c|c|}
\hline France & $\begin{array}{l}\text { France labor } \\
\text { cooperative } \\
\text { union } \\
\text { association } \\
\text { (CGSCOP) }\end{array}$ & $\begin{array}{l}\text { Social economy middle support institution } \\
\text { Taking charge of the role as lobby organization to the } \\
\text { government, start-up of cooperative unions under the } \\
\text { association, and operation consulting } \\
\text { Conducting assigned duties from the government such as } \\
\text { the role of writing cooperative union related statistical } \\
\text { data, securing support fund for each project from the } \\
\text { government, and operating with the membership fee of } \\
0.3 \% \text { out of the sales of association members. }\end{array}$ \\
\hline
\end{tabular}

\footnotetext{
${ }^{1}$ Kim Seong Gi et al. 4. Public market marketing for social economic companies-for innovative public service-Arche. 2015

${ }^{2}$ Thierry Jeantet. 2018 Social Economy International Forum - Regional Economic Development and Social Economic Innovation. 2018.01.

${ }^{3}$ Thierry Jeantet. 2018 Social Economy International Forum - Regional Economic Development and Social Economic Innovation. 2018.01.

${ }^{4}$ Gimhae city. A Study on the Operation Plan of Gimhae Social Economic Support Center. 2018.2
} 


\begin{tabular}{|c|c|c|}
\hline & & $\begin{array}{l}\text { Conducting consulting for start-up and management such } \\
\text { as professional law and accounting advisory, and the role } \\
\text { of cooperative union diligence of the government } \\
\text { Achieving the goal of labor cooperative union with } 2,000 \\
\text { members, } 45,000 \text { union members, and profits of } 5 \text { billion } \\
\text { euros per year }\end{array}$ \\
\hline & $\begin{array}{l}\text { France } \\
\text { commercial } \\
\text { cooperative } \\
\text { union groups } \\
\text { (Federation du } \\
\text { Commerce } \\
\text { Cooperatif et } \\
\text { Associ) }\end{array}$ & $\begin{array}{l}\text { Commercial cooperative union groups (FCA) established } \\
\text { in } 1963 \text { is a non-government institution which conducts } \\
\text { activities without doing businesses and also a non- } \\
\text { business group with } 6 \text { employees. } \\
\text { - Congress lobby activities to the government for improving } \\
\text { laws and institutions } \\
\text { - Performing function of promoting to the public of the } \\
\text { commercial cooperative union groups and educational } \\
\text { institutions such as universities } \\
\text { Performing advisory function regarding taxation and } \\
\text { consumer related laws to the member union }\end{array}$ \\
\hline The U.K. & $\begin{array}{l}\text { The U.K. } \\
\text { community link } \\
\text { (Community } \\
\text { Link) }\end{array}$ & $\begin{array}{l}\text { - An institution to support community service start-up } \\
\text { consulting } \\
\text { Rapid growth from start-up consulting order to obtain order } \\
\text { of consignment business of the government' s public } \\
\text { service and cooperative system establishment with } \\
\text { regional society organizations } \\
\text { Consignment of the consulting business to foster social } \\
\text { company, the implementation business of social service } \\
\text { consignment policy caused by the financial pressure of } \\
\text { the government } \\
\text { After building service space by receiving capital transfer } \\
\text { regarding a building from the government, establishing } \\
\text { consignment business of start-up consulting and } \\
\text { cooperative system with regional organizations, and } \\
\text { expanding business through the development of } \\
\text { programs to strengthen capability of social entrepreneurs } \\
\text { After starting a business through bus purchase and } \\
\text { operation in a backward port area about } 40 \text { years ago, in } \\
2013 \text { it implemented about } 40 \text { projects and } 3 \text { government } \\
\text { campaigns, and grew unto a support institution providing } \\
\text { social service to approximately } 20,000 \text { local citizens. }\end{array}$ \\
\hline & $\begin{array}{l}\text { British } \\
\text { Social } \\
\text { Investment }\end{array}$ & $\begin{array}{l}\text { - An institution to support social company operation fund } \\
\text { Emerged as a social economy representing financial } \\
\text { institution by conducting investment consulting including }\end{array}$ \\
\hline
\end{tabular}




\begin{tabular}{|c|c|c|}
\hline & Bank & $\begin{array}{l}\text { loan after securing the right to operate fund for fostering } \\
\text { social companies from the government } \\
\text { Labor party government raised the adventure capital fund } \\
\text { of } 87 \text { million pounds for fostering of social companies, } \\
\text { consignment institutions of social service and entrusted it } \\
\text { to SIB } \Rightarrow \text { On the condition that the fund of } 78 \text { million } \\
\text { dollars is donated to SIB depending on the project } \\
\text { success for } 10 \text { years. } \\
\text { Providing the fund of } 10,000 \text { pound when an early project } \\
\text { model is established, offering tailor-made loan condition } \\
\text { to support operation fund and investment strategy } \\
\text { consulting when a business is operated, and operating a } \\
\text { cooperative system with other social economy middle } \\
\text { support institutions. } \\
\text { Being entrusted with the fund of } 78 \text { million pounds in the } \\
\text { early } 2013 \text {, and } 320 \text { million pounds of other project fund } \\
\text { from the government, and a total of } 400 \text { million pounds } \\
\text { and } 6 \text { funds are operated. }\end{array}$ \\
\hline Sweden & Coompanion & $\begin{array}{l}\text { - Local cooperative union development institution } \\
\text { After the conservative party took power because of } \\
\text { economic crisis, privatization regarding social service was } \\
\text { pushed ahead, and the cooperative union emerged as a } \\
\text { consignment institution } \\
\text { - As non-profit facilitation policy in which social economy is } \\
\text { led by the government, social service niche market such } \\
\text { as caring is conferred to cooperative unions. } \\
\text { For vitalizing cooperative unions with the lead by the } \\
\text { government, } 25 \text { coopanions which benchmarks British } \\
\text { local development institution are installed and operated in } \\
\text { each area. } \\
\text { Each area' s coopanion consisted of about } 200 \text { members } \\
\text { is composed of } 1 \text { secretariat and } 7 \text { consultants and } \\
\text { horizontal networks are connected. } \\
\text { Three projects such as new cooperative union } \\
\text { development, start-up consulting regarding project model, } \\
\text { and local development related project are implemented. } \\
\text { With the start of early joint child rearing cooperative union, } \\
\text { through welfare and nursing home, recently about } 120 \\
\text { cooperative unions such as culture. housing related } \\
\text { cooperative union per year are developed. } \\
50 \% \text { of operation fund is raised from local governments }\end{array}$ \\
\hline
\end{tabular}




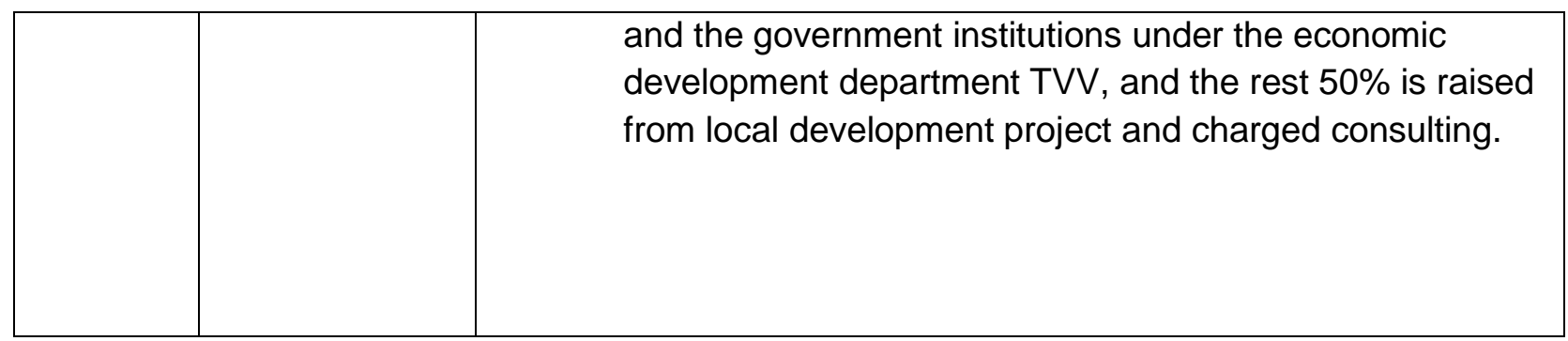

Source: Social share economy facilitation strategy of Gimhae city, 2015

Current Europe' s social economy is developing while leading new services in all areas such as economy, finance, health, society, and sports, and niche markets. Even though there are differences in the development level depending on area, it receives attention as an important actor which continuously has taken root in Europe's social economic environment ${ }^{1}$.

\section{Social Economy of Gimhae City}

Gimhae city is located in southerneast part of Gyeongsangnamdo, and it is near Busan metropolitan city, Milyang, and Yangsana in terms of administrative districts. As for the charateristis, it is a unique complex city composed of cultural relics, premodern city, rural area, new city, and company complex, and it is a city from the begin of Busan new port. As one of the biggest city in terms of population among bases of ancient kingdom in the Korean Peninsula. In addition, Gimhae city account for about $0.5 \%$ of Korea' s total area and about $4.4 \%$ of the total area of Gyeongsangnamdo, which is the $13^{\text {th }}$ largest among 20 cities and counties in terms of area ${ }^{2}$.

\footnotetext{
1 Thierry Jeantet. 2018 Social Economy International Forum - Regional Economic Development and Social Economic Innovation. 2018.01.

${ }^{2}$ Gimhae city hall. http://www.gimhae.go.kr
} 
Figure 1: Gimhae-si Map

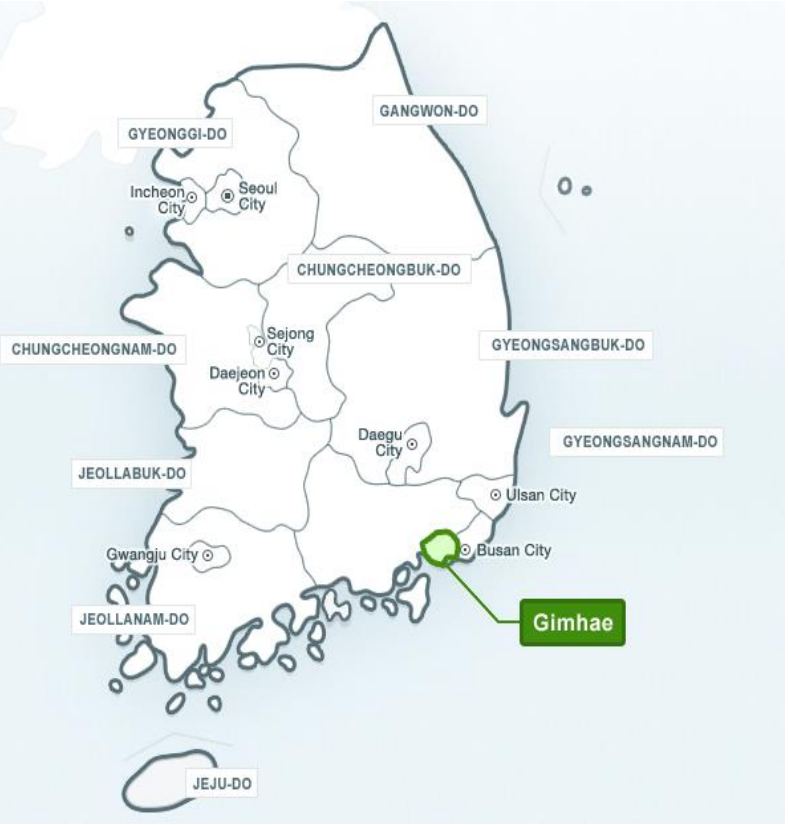

Source: Jeon Han, Gimhae City Hall

\subsection{Social Economy's Status and Characteristics of Gimhae City}

Gimhae city enacted 'Gimhae city social community fostering - support ordinance' in order to vitalize social economy and to create jobs in 2017. Private and public areas' activities became vibrant, there is high interest in social economy, and various kinds of approaches and attempts are being made. In private areas, 'Cafe Timor' and 'Tong cafe' established social companies with the aim of creating jobs for immigrant women, and 'Hoihyundang social cooperative union' was established to create jobs for elderly people who collect waste papers for their livelihood. In addition, on 'Bongridangil' where cultural streets are made, 'Fun people cooperative union' is doing it activities as a cooperative union organized by cultural and art related people. As 'JJ culture art cooperative union'. a puppet theater company operated by culture, art experts and village residents is combined, 'Bongridangil' is rapidly vitalized'.

In public areas, centering on original downtown established through Gimhae city's city revitalization support center, 'Ddookttakddoottak village carpenter cooperative union' and 'growth ring cooperative union' established for the purpose of house repair, and 'Namsan cultural village cooperative union' which provides consulting for providing jobs of lowincome elderly people, and 'Sigeumteolteol cooperative union established to restore traditional Makgeolli. In addition, 'Hoihyunyeonga social cooperative union; which was developed for food business centering on cheese manufacturing and cheese making experience and cheese with the main ingredient of milk produced in Gimhae built a

${ }^{1}$ Supporting social economy support center. Gimhae News. 2018.04.18 
cheese research center in March through years of planning in order to create social jobs for parents with incurable disease and cheese research and process are proceeded. In addition 'Oisong village cooperative union' and 'Alrokdalrok jewelry cooperative union' are being prepared to be established and brilliant ideas and feasible projects utilizing local resources are fostered and implemented ${ }^{1}$.

\subsection{Social Economy Support Policy of Gimhae City}

With gradual establishment of legal foundation related to social economy in the government, the interest in social economy is increasing and the importance in Gimhae city is growing. For facilitating regioanl community projects through social company creation and fostering support, for the first time in Gyeonnamdo, the ordinance of social economy facilitation was enacted and 'social economy support center' is going to be established for the first time in Youngnam area. As for the support to vitalize ordinance, there are education training for finding and fostering social companies, research. management support, facility expense and other various project support, sale outlet facilitation plan of priority purchase system, expanding participation by private sectors, and promotion and excellent case finding and expanding support ${ }^{2}$.

In addition, for the first time in Yeongnam area, with the expected establishment of 'social economy support center' in September, 2018, it seems that the investment in social economy increases and real operation and facilitation of companies will be realized in Gimhae city due to the establishment and operation of social economy center. Gimhae city' s social economy support center plans to operate social economy organization fostering policy by providing indirect support such as social economy organizations' company management, taxation, and start-up consulting, and direct support such as purchase of $7 \%$ of social economy organizations' product to public institutions ${ }^{3}$.

Gimhae city will continue to make efforts to create jobs by actively fostering social economy companies, to enhance quality of living, and to vitalize economy structure centering on people.

\subsection{Research on Actual Condition of Social Economy Activists of Gimhae City}

Research was conducted on social economy organization and activists in Gimhae city, and the research was conducted through interview. The research contents include establishment time, establishment purpose, establishment leader, business

\footnotetext{
${ }^{1}$ Supporting social economy support center. Gimhae News. 2018.04.18

${ }^{2}$ Ordinance of Gimhae city social community fostering support

3 "Vitalizing social economy" .... 10 companies push for start-up. Gimhae News. 2018.01.10
} 
contents(kinds/methods), employment, customer composition, sales structure, government' s support and support details, required support policy, and social economy model suitable for Gimhae city. The research was conducted on 14 companies and 21 activists.

The research found that most of the companies were established after 2009, and the establishment purpose is mainly to help self-support and support for socially underprivileged, and followed by the purpose of vitalizing regional community. Establishment was led by self-support businessmen, consumer association, city hall consignment businessmen, corporate businessmen, regional artists and art consumers, cooperation between individuals or acquaintances, company affiliation, producer association, and village community and other various types.

The business kind was various such as service, construction, wholesale and retail, multicultural cafe, hygiene management, and elderly nursing institutions. The number of employees of the researched 14 companies is 13.5 on average, and the number of employees who bought work medical insurance was 10.6 on average. Customer composition includes various customers such as people in certain age group, elementary - middle high school, public office/company. Disabled people, disadvantaged people, and low-income people. As for the sale structure, 'service provision business and service' accounted for the most part, followed by 'product sale'. The companies which receive support from the government is less than $50 \%$, resources came from the government fund, Gyeongnamdo, Gimhae city hall, and local rehabilitation center. Support details include personnel expense, finance support business, and job creation business. To the question about which policy is the most needed for vitalizing social economy of Gimhae city, there were answers such as 'operation expense, personnel expense, facility expense, tax reduction and other subsidy support(10 people)', 'support to people working in Gimhae city social economy(8 people)', 'market opening and on- offline joint store opening support(7 people)' in that order. The social economy model suitable for Gimhae city were 'welfare model for socially disadvantaged people(disabled people, low income people, and the elderly)(8 people)', 'history culture tourism centered model based on Gimhae' s history(6 people)' , and 'village community centering model utilizing characteristics of rural areas of Gimhae city(4 people)’ .

Research analysis found that the absolute number of social companies in Gimhae city is insufficient and the ratio of self-supporting companies is high, and the activities of local self-supporting centers is relatively vibrant, but they are in the rudimentary stage in the social economy development. The standard deviation is very wide from 1 to 59 in the number of employees. Therefore there could be companies having difficulties in real operation, and it is important to increase social companies, but normalizing operation by conducting consulting to companies where real operation is suspended. Social economy 
activists were demanding direct fund support, and there were demand for indirect support such as support for network organization of interested people, market opening, and priority purchase system.

In the case of Gimhae city, the population is about 53,000 and 250 company businessmen(assumed), at $0,047 \%$ compared with the population, which is less than $30 \%$ of Seoul city or one sixth of Seoul city. The social economy size of Gimhae city is relatively poor compared with other regions and the growth of social economy organizations is just maintained.

\section{Conclusion}

Currently, social companies recognized in Korea is showing rapid growth until now. Local autonomous governments established social economy support center and are conducting projects to secure finance resources needed for supporting local autonomous government social economy organization for self-supporting ability and sustainable growth of social economy companies such as social company, cooperative union, and village company ${ }^{1}$.

With the legal ground established related to social economy currently, the interest in social economy is increasing and the importance is growing in Gimhae city. Therefore, Gimhae city enacted ordinance of social economy vitalization for the first time in Gyeongnamdo in order to vitalize local community businesses by supporting and fostering social company start-up, and with the plan to establish 'social economy support center' for the first time in Yeongnam area in September 2018, only in the middle and late 2010 private sectors and the government began to realize the necessity for vitalizing social economy.

Current status of social economy in Gimhae city suggest that activities of private and public sectors became vibrant, and there are high interest and various approaches attempted regarding social economy. However, as of December, 2017, there are 23 companies as social economy organizations.

According to the research through interview on social economy activists in 2009, most companies began to be established since 2009, and there were various kinds of businesses such as service, construction, wholesale and retail, multicultural cafe, hygiene management, and elderly nursing institution. As for sale structure, 'service provision business and service provision' , and 'product sale' accounted for the most part. As for the policy most needed for vitalizing the social economy in Gimhae city, there were answers such as 'subsidy support such as operation expense, personnel expense,

${ }^{1}$ Korea Basic Law on Social Economy 
facility expense, and tax reduction' , 'support to people working in Gimhae city social economy' , and 'market opening and on-offline joint store opening support' in that order.

Analysis found that, Gimhae city's social economy has insufficient number of social companies in the absolute number, and the ratio of self-supporting companies was high. Even though the activities of local self-supporting center were vibrant, they were at the rudimentary stage in the social economic development. In addition, there would be companies with difficulties of real operation, it is needed to normalize operation through consulting for the companies whose operation was suspended. Less than $50 \%$ companies received the support from the government, and social economy activists needed direct resource support, and indirect support such as support for network organization of interested people, market opening and priority purchase system.

Therefore, for vitalizing Gimhae city's social economy and growth, not the policy focusing only on quantitative index, but consulting and active resource support are needed to increase the autonomous ability. In addition, there is a need for promotion and education social economy activists and citizens, and active exchanges with the administration for social economy activists to acquire information on various support. Rather than direct support from the government and local autonomous government, professional support activities where private sectors participate in Gimhae city' s social economy support center is needed.

In the future, this study is expected to provide basic data regarding social economy, suggest measures for social economy development and facilitation of Gimhae ciy, and seek desirable directions.

\section{Reference}

Five researchers including Lim Sang Yeon and et al. Measures to utilize social economy organization for increasing ciy vitality. KRIHS POLICY BRIEF. no. 556. 2016

Gimhae city. A Study on the Operation Plan of Gimhae Social Economic Support Center. 2018.2

Gimhae city hall. http://www.gimhae.go.kr

Korea Basic Law on Social Economy

Kim Seong Gi et al. 4. Public market marketing for social economic companies-for innovative public service-Arche. 2015

Kwon Eun Sil. A Study on the Present Situation and development measures of Social Enterprise -With Emphasis on Daegu and North Gyeongsang Province-. Daegu university master's thesis. 2011

Lee Yu Ri. A Study on the Current Stateand Development Plan of Social Economic Organization -Focusing the Jeollanamdo-. Mokpo university master's thesis. 2015 
Ministry of Strategy and Finance of the Republic of Korea

ModuCoop. Comparative study of social economy-related regulations and policies across the nation's metropolitan cities -Focusing social company, cooperative union-

Ordinance of Gimhae city social community fostering support

Social Economy Europe. www.socialeconomy.eu.org.

Social Share Economy Facilitation Strategy of Gimhae City. 2015

Supporting social economy support center. Gimhae News. 2018.04.18

Thierry Jeantet. 2018 Social Economy International Forum - Regional Economic Development and Social Economic Innovation. 2018.01.

“Vitalizing social economy" .... 10 companies push for start-up. Gimhae News. 2018.01.10 